\title{
Human Resources as a Factor in Strengthening the Competitiveness of Enterprises Trade Sector Puerto Vallarta, Jalisco.
}

\author{
Dr. Manuel Ernesto Becerra Bizarrón ${ }^{1}$, Mtra. Elba Martina Cortes Palacios ${ }^{2}$, \\ Mtro. Jose Luis Bravo Silva ${ }^{3}$, \\ Researcher at the University of Guadalajara.
}

\begin{abstract}
Globalization has affected micro, small and medium sized enterprises and their functional areas. Multiple research approaches have been conducted regarding this issue, however there is not a specific document to address it in Puerto Vallarta in order to improve and sustain the competitiveness of this sector. The purpose of this project is to analyze micro, small and medium sized enterprises competitiveness framework and portray how human resources are important to address change processes that are needed in the retail sector. The methodological strategy followed in this researchwas based on a deductive method, describing the competitiveness factors proposed by the Inter-American Development Bank, focusing in human resource as change factor in retail micro business in Puerto Vallarta.
\end{abstract}

Keywords: Competitiveness, Microenterprise, Retail

\section{Introduction}

SME's have become relevant for most economies worldwide, in Spain according to National Statistic Institute (2013) 99.9\% of existing companies are considered SME's where small enterprise represents $42.2 \%$. Retail sector represents $27.1 \%$ a similar situation occurs in Japan and Korea.

InMéxicoaccording to statistics from INEGI (2014), a pyramid represents the business structure where $95.2 \%$ of micro enterprises represent $45.6 \%$ of labor force. Small business employ $4.3 \%$ of workforce and 23.8 $\%$; of medium sized businesses that represent $0.3 \%$ employ $9.1 \%$ of available workforce. The remaining $0.2 \%$ of large companies which employ $21.5 \%$ of reported personnel.

In recent years, the performance of the Mexican economy has been favorable, however, there are still structural factors that need to be addressed, among which include low staff productivity, growth thereof and dissemination of technologies information (Gutiérrez 2013). Micro, small and medium enterprises are a key element for economic development of the country and the State of Jalisco, both for its contribution to employment, and its contribution to gross domestic product, constituting, for this investigation, more than $98 \%$ of all economic units, representing around 52\% of GDP and help to generate more than $73 \%$ of formal jobs (Navarrete, Hernandez, \& Abadie, 2011).

The GDP of the State of Jalisco of \$ 722.5 billion pesos, and this value, three sectors account for the majority with $53.7 \%$ manufacturing with $22.6 \%$, industry and commerce $21.2 \%$ and real estate and rental furniture and intangible assets with 10.8\% (INEGI 2011).

According to Sistema de Information del Estado de Jalisco (2009). The business structure of the state is composedby a total 157.368 enterprises, of which $94.8 \%$ are micro, $4.2 \%$ small $0.7 \%$ medium and $0.3 \%$ large. 99.7\% ofcompanies in Jalisco are MSMEs accounting for 156.895 (SEIJAL 2009). The state government of Jalisco is committed to the economic development of the state, the government claims that the actions plans, policies and programs in economic development which are carried out with proper alignment to the National Development Plan 2013 - 2018 and State Economic Development plan 2013-2033 Jalisco are focused in improving competitiveness of companies.

Therefore, the Program Jalisco Competitivo (Secretaria de Desarrollo Económico Jalisco, 2014) search for the welfare and economic development to contribute to the actions and strategies that have arisen in the development dimension for welfare: Prosperous economy and Inclusive through sectoral themes

1. Employment and human capital

2. Financing and entrepreneurship

3. Competitiveness and economic growth

4. Tourism development

5. Rural development

6. Innovation, science and technology 
The problems of microenterprise in Puerto Vallarta are the result from various failures, mainly to limited access to financing, technical assistance, lack of prospects and scarce training to people. Furthermore, in the case of the latter lack of knowledge and technical skills causes failures in administrative function procedures, the lack of management skills causes incompetence of the manager or administrator, attributing $40 \%$ of the bankruptcy of this business (Dominguez 2010).

According to Dominguez (2010) in Puerto Vallarta the problems of SMEs that cause the failure are due mainly to:

- Poor access to financing,

- Technical assistance,

- $\quad$ Lack of leadership

- $\quad$ Lack of training of employees.

According to previous analysis of the context of business, and the problems identified, the aim of this research was to analyze competitiveness of micro business and the importance of human resources for their processes in the commercial sector of Puerto Vallarta Jalisco, in order to develop a platform that allows to detect improvement factors to address microenterprises to strengthen its growth.

The research approach was qualitative by the nature of the variables, the method was deductive, a contextual and theoretical analysis was developed to analyze the problems of commercial SMEs in Puerto Vallarta, a comparative analysis of models was developed in order to measure sectorial and enterprise competitiveness, and therefore an instrument that will integrate aspects identified in the theoretical review was defined. A non experimental design was used without control of the independent variables, a descriptive scope was intended to analyze and describe the competitiveness of SMEs and areas for improvement were identified. The instrument developed by the Interamerican Development Bank was used, as proposed by Saavedra (2012) 9 factors to analyze micro - level competitiveness. The sample with finite population formula was determined, 165 companies were sampled from a universe of 1154 according to the SIEM, with a statistical confidence level of $.95 \%=1.96$

To develop the questionnaire to measure the competitiveness, 44 authors and 62 factors were analyzed to analyze the contexts in which they were used and identify the consistency with the aim of research. The sections of the questionnaire were: 1. Strategic Planning (Process, Implementation, Planning), 2. Production and operations (Quality, Maintenance and Research and Development, Procurement, Inventory Management \& Location Infrastructure), 3. Quality Assurance (General Aspects Systems) 4. Marketing (Nacional- Market and Sales, Services, Distribution) 5. Accounting and Finance (Cost Monitoring and Accounting, Administration, Legal and Tax Regulations) 6. Human Resources (General aspects, Training and Promotion staff, Organizational Culture, Health and Industrial Safety) 7. Environmental Management (Policies, Strategies to Protect the Environment, Awareness and Training Administration of Waste) 8. Information Systems (Planning, Inputs, Process, and outputs) and 9. Resources (Infraestructure, Economics, government) a section was added to analyze the view of entrepreneur infrastructure, economy, government and natural resources context. 123 questionswere answered with a Likert scale of 1 to 5 where 1 from strongly disagree and 5 fully agree.

\section{Theoretical Aspects.}

Theory of competitive advantage, where the diamond of competitiveness (Porter 1990) mentioned was analyzed, the structure was also analyzed the systemic competitiveness of all levels (Esser and Hillebrand 1994) the relationship between the competitiveness of enterprises and production variables cost: (Benavides, Muñoz and Parada 2004). Generally there are 7 areas that are integrated into a business and that are part of the competitive factors of a company (Horta, Silveira and Camacho 2013):

Production, development of products and service, human resources, marketing, accounting and finance, management. Neoclassical economic theory is limited for dynamic analysis. microeconomic theory does not have a general explanation of why some firms gain market share at the expense of rivals (assumes that all have the same technique and the same cost structure, and both market share equally in both perfect competition and monopolistic competition). And this is also the reason that conventional theories of international trade find no explanation for the fact that some countries tend to gain world market shares persistently, while other countries are reduced gradually, but steadily, their participation in it as Bajo (1991) cited by (Commerce 2014).

The models that have tried to approach the phenomenon of insertion to explain or predict this process can fall into two categories. Those arising from theoretical conceptions about how and why it happens and those derived from empirical approaches. The former have the advantage of representing a globalist approach of the process where relevant variables are grouped, in return still need to be experienced in practice. Empirically based models have his credit with an analysis of reality and therefore with the consequent verification of variables including, but have the disadvantage to be partial and limited to very specific environmental contexts and populations. However, in one and three interacting systems are observed: the applicant a job, or is the 
subject you want access to a job with specific characteristics; the labor market, with the characteristics of the employer and recruitment processes and flow between supply and demand; and finally, economic policy established by the legislation regarding hiring and employment support features to be competitive.

Insertion companies are companies that, duly qualified, productive work performed by participating in the market through the production of goods or provision of services. These companies are primarily to their corporate purpose the socio-professional integration of people experiencing social exclusion, by developing a personal project of insertion by providing gainful employment, training and support needed to improve their employability as transit to mainstream employment and become a competitive company (Donoso 2000).

Theory Corporate Competitive Strategy in the analysis of competitive advantages, the company is divided into different activities identified as units that provide competitive differentiation and cost advantages. Each of these units should generate customer value and referred to as the value chain of the company. It also includes the concept of Drivers, which are determinants that mark the differences between competitors such as the following: accumulated knowledge, brand image, location of activities and the level of integration. Analyzing in depth the dimensions to identify the true source of competitive advantage. Strategic decisions depend on the position of the company in the sector, which can be evaluated by way of the value chain and drivers (Economist 2013).

Theory of Transaction Costs has been proposed as an explanatory theoretical model of cooperation agreements. According to this theory, cooperation, at times, allocate resources more efficiently than the market and the company hierarchy. In this perspective, the cooperation becomes an intermediate point of connection between the market and the company under some circumstances, correct market imperfections and becomes more flexible and dynamic hierarchies, to meet the changing environment. The company will have to always decide what would be the best choice of the three: market, internalization, or cooperative agreement. Theory of Transaction Costs establishes a theoretical basis for understanding the relations of cooperation, its advantages over the market or the company (Sanchez 2010).

Theory Factors of Competitiveness adopts raised by the European Management Forum. This choice is made because, firstly, the conception of the EMF believes that competitiveness is an ability of the company, reflected in the competitive advantages created from the interrelationships that are generated in different organizational processes and allow is better than competitors in the same market. Second, because in a market economy, consumers are demanding benefits that go beyond offering low prices; ie require them attributes that better meet their needs. And finally, because it is in the market which reflects how competitive a company, although competitiveness is built from its internal areas. To the extent that progress in the field work with entrepreneurs and experts will discuss whether this concept is consistent with the factors defined for the design and methodology (Cabrera, Lopez and Ramirez 2011) variables.

\section{Results.}

Competitiveness was measured based on final scores, each level was divided in 4 levels. The lowest level is represented by 1 (1-154 score) low level (155-307 score), medium level 3 (308 - 461 score), High level, 4 (462 - 615 score).Global competitiveness level was very low for $11.63 \%$ of the cases, low for $36.36 \%$ medium for $27.91 \%$ and high for $23.84 \%$ of the cases.

Graphic 1.- Competitiveness levels

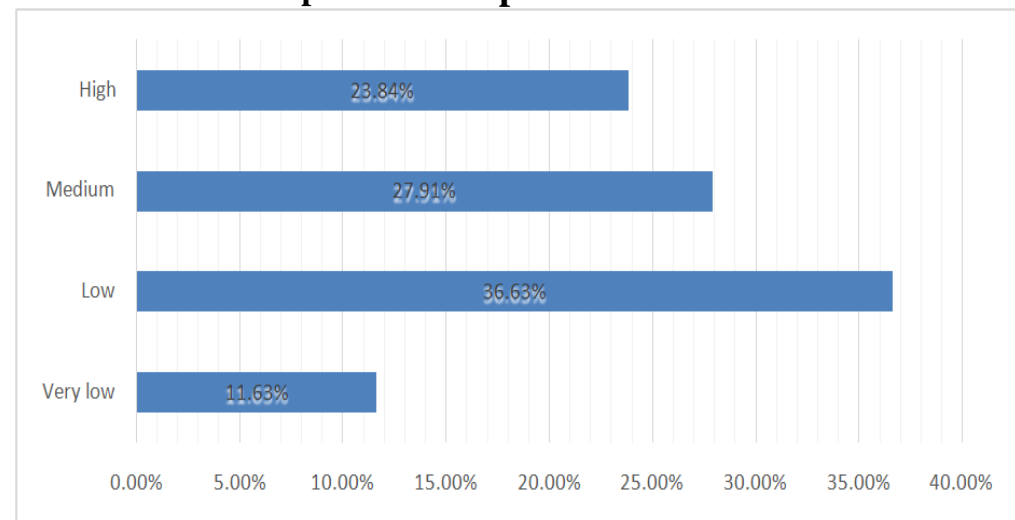

Source: Primary data

Global competitiveness of commercial sector by factors

Accounting and finance is the highest value with 3.63 and the lowest Environmental management with 2.82 


\section{Graphic 2:Global Competitiveness Factors}

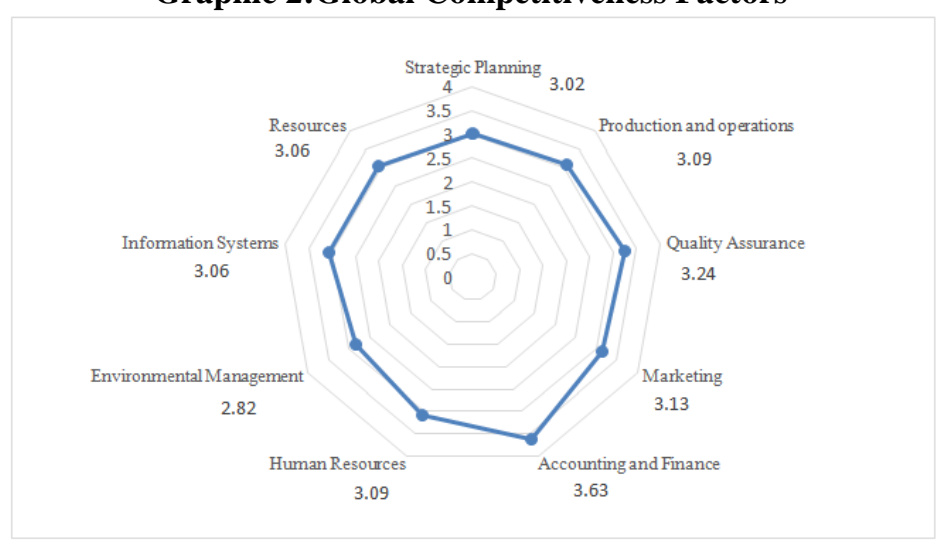

Source: Primary data

\section{Competitivenessof commercial sector enterprises by size.}

Table 1 shows the overall level of competitiveness for micro enterprises. $89.5 \%$ of the cases were micro business, $8.7 \%$ were small and $1.7 \%$ was medium. Considering the scored competitiveness levels, in the lowest level, $95 \%$ of total business were micro business and $5 \%$ were small. In the low competitiveness level 93.7\% were micro, $4.8 \%$ small and $1.6 \%$ medium. In the medium competitiveness level $93.8 \%$ were micro, $4.2 \%$ small and $2.1 \%$ medium. In the highest competitiveness level $75.6 \%$ were micro, $22 \%$ small and $2.4 \%$ medium.

Table 1: Competitiveness levels - size companies

\begin{tabular}{|c|c|c|c|c|c|}
\hline & & \multicolumn{3}{|c|}{ Size companies } & \multirow[t]{2}{*}{ Total } \\
\hline & & Micro & Small & Medium & \\
\hline \multirow{5}{*}{$\begin{array}{l}\text { Very low } \\
\text { Low } \\
\text { Medium } \\
\text { High }\end{array}$} & Count & 19 & 1 & 0 & 20 \\
\hline & $\%$ within levels of competitiveness & $95.0 \%$ & $5.0 \%$ & $0.0 \%$ & $100.0 \%$ \\
\hline & $\%$ within levels of competitiveness & $93.7 \%$ & $4.8 \%$ & $1.6 \%$ & $100.0 \%$ \\
\hline & $\%$ within levels of competitiveness & $93.8 \%$ & $4.2 \%$ & $2.1 \%$ & $100.0 \%$ \\
\hline & $\%$ within levels of competitiveness & $75.6 \%$ & $22.0 \%$ & $2.4 \%$ & $100.0 \%$ \\
\hline \multirow[t]{2}{*}{ Total } & Count & 154 & 15 & 3 & 172 \\
\hline & $\%$ within levels of competitiveness & $89.5 \%$ & $8.7 \%$ & $1.7 \%$ & $100.0 \%$ \\
\hline
\end{tabular}

Source: Primary data

\section{Competitiveness Factors by Size}

According to graphic 3 the factors were scored as follows: Accounting and Finance was the highest factor with a score of 3.53 followed by quality management with 3.18 , commercialization 3.07, 3.03 resource allocation, 3.00 production and operations, 2.98 human resources, 2.96 information systems, 2.94 strategic planning, 2.75 the lowest for environmental management.

\section{Graphic 3: Competitiveness Factors of Micro Commercial Business}

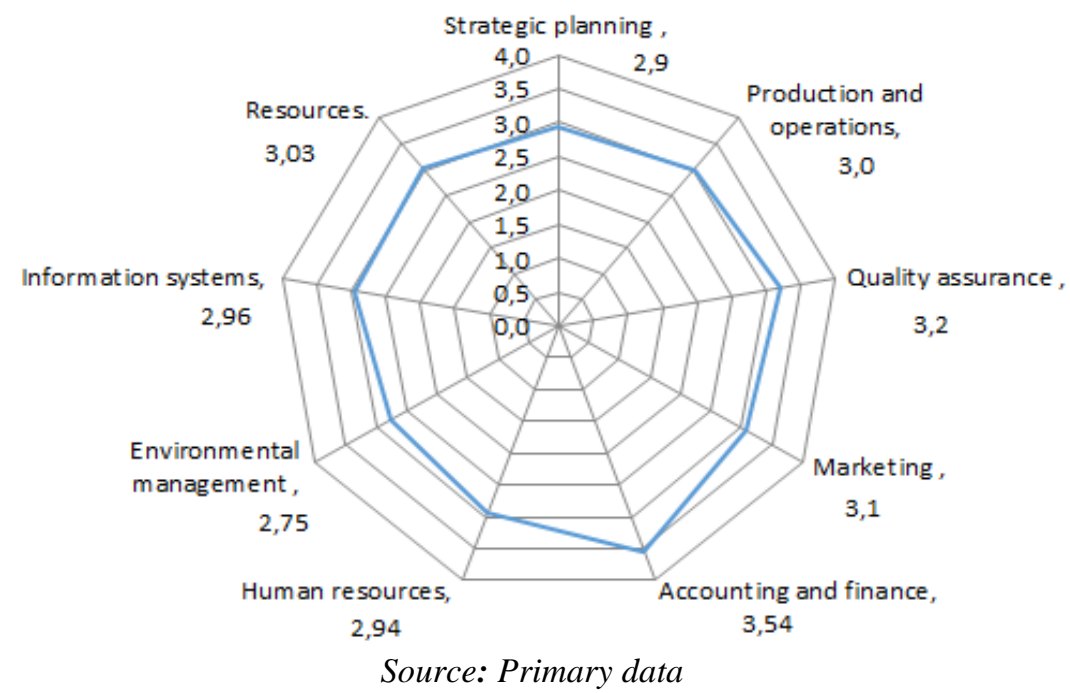


Focused in human resource management, three aspects: training and promotion, health and safety, organizational culture were measured using a scale from 1 to 5 were 1 represented a non existent process, 2 in process, 3 documented process, 4 documented and operating process, 5 documented, operating and evaluated process in order to correlate the before mentioned factors with the competitiveness levels. Table 2 shows that $29.2 \%$ of micro business were in medium competitiveness level had an organizational culture documented and operating $20.1 \%$ of business in high competitiveness level had a documented, operating and evaluated organizational culture.

Table 2.- Organizational Culture and Competitiveness Level.

\begin{tabular}{|c|c|c|c|c|c|c|c|}
\hline \multirow{2}{*}{\multicolumn{3}{|c|}{ Business Sectors }} & \multicolumn{4}{|c|}{ Competitiveness levels } & \multirow[t]{2}{*}{ Total } \\
\hline & & & Very low & Low & Medium & High & \\
\hline \multirow[t]{6}{*}{ Commerce } & \multirow[t]{5}{*}{ Organizational culture } & 1.00 & $69.2 \%$ & $30.8 \%$ & & & $100.0 \%$ \\
\hline & & 2.00 & $31.8 \%$ & $54.5 \%$ & $13.6 \%$ & & $100.0 \%$ \\
\hline & & 3.00 & $7.9 \%$ & $68.4 \%$ & $23.7 \%$ & & $100.0 \%$ \\
\hline & & 4.00 & & $21.2 \%$ & $63.6 \%$ & $15.2 \%$ & $100.0 \%$ \\
\hline & & 5.00 & & $20.8 \%$ & $25.0 \%$ & $54.2 \%$ & $100.0 \%$ \\
\hline & \multicolumn{2}{|l|}{ Total } & $12.3 \%$ & $38.3 \%$ & $29.2 \%$ & $20.1 \%$ & $100.0 \%$ \\
\hline
\end{tabular}

Source: Primary data

Table 3 shows that $49.1 \%$ of micro business were in medium and high competitiveness levels and most of training and promotion aspects were documented, operating and evaluated.

Table 3. Training and Levels of Competitiveness

\begin{tabular}{|c|c|c|c|c|c|c|c|}
\hline \multicolumn{3}{|c|}{ Business Sectors } & \multicolumn{4}{|c|}{ Competitiveness levels } & \multirow[t]{2}{*}{ Total } \\
\hline & & & Very low & Low & Medium & High & \\
\hline \multirow[t]{6}{*}{ Commerce } & \multirow[t]{5}{*}{ Training } & 1.00 & $38.1 \%$ & $57.1 \%$ & $4.8 \%$ & & $100.0 \%$ \\
\hline & & 2.00 & $26.5 \%$ & $52.9 \%$ & $20.6 \%$ & & $100.0 \%$ \\
\hline & & 3.00 & $3.7 \%$ & $74.1 \%$ & $22.2 \%$ & & $100.0 \%$ \\
\hline & & 4.00 & $3.2 \%$ & $19.4 \%$ & $64.5 \%$ & $12.9 \%$ & $100.0 \%$ \\
\hline & & 5.00 & & $7.3 \%$ & $26.8 \%$ & $65.9 \%$ & $100.0 \%$ \\
\hline & \multicolumn{2}{|l|}{ Total } & $12.3 \%$ & $38.3 \%$ & $29.2 \%$ & $20.1 \%$ & $100.0 \%$ \\
\hline
\end{tabular}

Source: Primary data

Table 4 shows that $49 \%$ of microbusiness were in the medium and high competitiveness levels, most of them had documented, operating and evaluated.

Table 4. General Aspects and Competitiveness Levels.

\begin{tabular}{|c|c|c|c|c|c|c|c|}
\hline \multirow{2}{*}{\multicolumn{3}{|c|}{ Business Sector }} & \multicolumn{4}{|c|}{ Competitiveness levels } & \multirow[t]{2}{*}{ Total } \\
\hline & & & Very low & Low & Mediu & High & \\
\hline \multirow[t]{6}{*}{ Commerce } & \multirow[t]{5}{*}{ General aspects } & 1.00 & $46.9 \%$ & $46.9 \%$ & $6.2 \%$ & & $100.0 \%$ \\
\hline & & 2.00 & $10.0 \%$ & $72.5 \%$ & $17.5 \%$ & & $100.0 \%$ \\
\hline & & 3.00 & & $35.7 \%$ & $53.6 \%$ & $10.7 \%$ & $100.0 \%$ \\
\hline & & 4.00 & & $16.7 \%$ & $66.7 \%$ & $16.7 \%$ & $100.0 \%$ \\
\hline & & 5.00 & & $3.3 \%$ & $16.7 \%$ & $80.0 \%$ & $100.0 \%$ \\
\hline & \multicolumn{2}{|l|}{ Total } & $12.3 \%$ & $38.3 \%$ & $29.2 \%$ & $20.1 \%$ & $100.0 \%$ \\
\hline
\end{tabular}

Source: Primary data

Table 5 shows that $49 \%$ of micro business had medium and high competitiveness levels had health and safety aspects operating and documented in a lesser extent they had evaluated processes.

Table 5. Health and Safety Aspects and Levels of Competitiveness

\begin{tabular}{|c|c|c|c|c|c|c|c|}
\hline \multirow{2}{*}{\multicolumn{3}{|c|}{ BUSINESS SECTORS }} & \multicolumn{4}{|c|}{ Competitiveness levels } & \multirow[t]{2}{*}{ Total } \\
\hline & & & Very low & Low & Medium & High & \\
\hline \multirow[t]{7}{*}{ COMERCIO } & \multirow[t]{6}{*}{ Health and security } & 1.00 & $39.1 \%$ & $56.5 \%$ & $4.3 \%$ & & $100.0 \%$ \\
\hline & & 2.00 & $18.4 \%$ & $65.8 \%$ & $10.5 \%$ & $5.3 \%$ & $100.0 \%$ \\
\hline & & 3.00 & $8.6 \%$ & $42.9 \%$ & $42.9 \%$ & $5.7 \%$ & $100.0 \%$ \\
\hline & & 4.00 & & $13.9 \%$ & $61.1 \%$ & $25.0 \%$ & $100.0 \%$ \\
\hline & & 5.00 & & & $14.3 \%$ & $85.7 \%$ & $100.0 \%$ \\
\hline & & 10.00 & & $100.0 \%$ & & & $100.0 \%$ \\
\hline & \multicolumn{2}{|l|}{ Total } & $12.3 \%$ & $38.3 \%$ & $29.2 \%$ & $20.1 \%$ & $100.0 \%$ \\
\hline
\end{tabular}

Source: Primary data 


\section{Conclusion.}

49.3\% of Microenterprise in the commercial sector tends to have a medium / high competitiveness level, the strongest factors affecting this improvement are production and operations, quality assurance, marketing, accounting and finance and resource management, factors to be strengthened in order to improve its competitive position are, strategic planning in order to establish the orientation and future business activities; that is linked to the role and work of senior managers, as well the human resources function that allows better management of human resources, conceived from a strategic approach as a business strategy that manifests the importance of individual relationship against relations collective among managers, directors or workers, promoting the active participation of all employees of the company. Environmental management to create strategies for social responsibility for the care of the environment, placed in a situation where social image can improve by doing so. Develop strategies to support operational functions through information technology are vital to develop a competitive business structure.

Focusing in human resources in the aspects of organizational culture, labor issues, health and hygiene at work, and training and career development, tend to have documented strategies but without operating, and much less evaluate them, a traditional operation system prevails in a turbulent environment.

\section{References}

[1] Banco interamericano de desarrollo. http://www.iadb.org/es/temas/competitividad-tecnologia-e-innovacion/competitividadtecnologia-e-innovacion, 1366.html.

[2] Benavides, Muñoz, and Parada. «Relación entre la competitividad de las empresas y las variables de Costos de Producción.» 2004.

[3] Cabrera, Martinez Alejandra, López Paula López, and Méndez Claudia Ramírez. La competitividad empresarial: Un marco conceptual para su estudio. Marzo de 2011. http://es.calameo.com/read/002822059026f4b299bf9 (accessed 28 de Junio de 2015).

[4] Domínguez, Aguirre L. «El perfil de la empresa en Puerto Vallarta.» Universidad de Guadalajara, 2010.

[5] Donoso, T. «La inserción socio-laboral: diagnostico de las variables relevntes.» 2000. http://www.ub.edu/gredi/wp-

[6] Economista. «Razones por las que las empresas tienen éxito o fracaso.» 12 de Abril de 2013. http://ecolisima.com (accessed 15 de Julio de 2015).

[7] Gutiérrez. «Impulso a la productividad para la competitividad, una propuesta para México.» Ciclo de conferencias foros y talleres. México: Foro consiltivo Científico y Tecnológico, AC, 2013. 205-215.

[8] Horta, R, L Silveira, and M Camacho. «Revista Iberoamericana de ciencia, tecnólogia y sociedad.» 2013. http://www.revistats.net/volumen-10-numero-28/294-articulos-633-competitividad-e-innovacion-en-la-industria-manufacturera-enel-urugay (accessed 30 de Julio de 2015).

[9] «INE.» España, 2013.

[10] «INEGI.» 2011. www.inegi.org.mx.

[11] INEGI. «Plan de Desarrollo Gerencial para las empresas Pymes de Educación Privada como estrategia para el fortalecimiento empresarial de Puerto Vallarta.» 2007. http://132.248.164.227/congreso/es/docs/anteriores/xix/docs/3.10.pdf (accessed 03 de Julio de 2015).

[12] Navarrete, Baéz Francisco Ernesto, Rodríguez Gabriel Hernandéz, and Morales René Abadie. «UNIVA.» 2011. http://www.univa.mx/cii/difcon/la-toma-de-decisiones-en-la-mipymes-1.pdf (accessed 25 de Julio de 2015).

[13] Porter, M. «De las teorias de la competitividad.»1990. http://132.248.9.195/pd2007/0618566/A4.pdf (accessed 30 de Julio de 2015).

[14] Sánchez, Castro John. «Teorías para el análisis de las principales fuentes de ventajas competitivas del sector metalmecánico del departamento de Risaralda Colombia.» Abril de 2010. http://www.redalyc.org/pdf/849/84917316017.pdf (accessed 22 de Julio de 2015).

[15] Saavedra, García María Luisa. «Una propuesta para la determinación de la competitividad en la pyme latinoamericana.» Redalyc, 2012: 93-124.

[16] «Secretaria de Desarrollo Economico en Jalisco.» 2014. http://sedeco.jalisco.gob.mx/temas-economicos/jalisco-competitivo (accessed 26 de Julio de 2015)

[17] «SEIJAL.» Sistema Estatal de Información Jalisco. 23 de Octubre de 2009. www.seijal.gob.mx (accessed 25 de Julio de 2015). 